\title{
Public Participation: What has the Constitutional Court given the public?
}

Merafong Demarcation Forum and Others $v$ President of Republic of South Africa and Others [2008] ZACC 10

\author{
LINDA NYATI \\ B Com (Law) student, University of the Western Cape
}

\section{INTRODUCTION}

The Freedom Charter ${ }^{1}$ declared many years ago that " $(t) h e$ People shall govern". When the constitutional drafters devised a legislative system for our democracy they might have had this slogan in mind. South Africa's constitutional democracy is representative and participatory in its nature. The representative aspect embraces multi-party democracy, achieved through regular elections based on a common voters' roll and proportional representation; ${ }^{2}$ the participatory aspect goes further than regular elections every five years in that it guarantees involvement of each citizen in public life in between elections. These two aspects should not be seen as conflicting with each other but as complementary. To this extent public participation is linked to the right to political participation. The right to political participation in terms of international law ${ }^{3}$ has expressly recognised the right to participate in public life. In other words, public participation in the legislative process is an integral part of any democracy.

In the Constitution of the Republic of South Africa ("the Constitution") the right to vote ${ }^{5}$ at regular elections guarantees a democratically elected government

1 The Freedom Charter adopted at the Congress of the People, Kliptown 1955.

2 Motala \& Ramaphosa Constitutional Law: Analysis and cases (2002) 9.

3 South Africa adopted the International Covenant on Civil and Political Rights on 3 October 1994 and ratified it on 10 December 1998.

Article 25 reads as follows:

Every citizen shall have the right and the opportunity, without any of the distinctions mentioned in article 2 and without unreasonable restrictions:

(a) to take part in the conduct of public affairs, directly or through freely chosen representatives;

(b) to vote and to be elected at genuine periodic elections which shall be by universal and equal suffrage and shall be held by secret ballot, guaranteeing the free expression of the will of the electors."

4 Formerly known as Act 108 of 1996.

5 S 19 (2) provides: Every citizen has the right to free, fair and regular elections for any legislative body established in terms of the Constitution. 
that is accountable, ${ }^{6}$ responsive and open ${ }^{7}$. The Constitution also specifies that the National Assembly, which is elected by the people, must ensure "government by the people under the Constitution ... by providing a national forum for public consideration of issues". ${ }^{8}$ It is sections 59(1)(a), 72(1)(a) and $118(1)(a)^{9}$ of the Constitution that establish public participation in the legislative process. When the public can participate in the legislative process, individually or as a collective, it signifies that everyone is regarded as significant and that their opinions are taken into consideration by the government. ${ }^{10}$

The Constitutional Court ("the Court") has on previous occasions been called upon to analyse and clarify the nature and extent of the obligation to "facilitate public involvement" in legislation and other processes placed upon legislative bodies by the Constitution. Most recently the Court addressed this issue in the case of Merafong Demarcation Forum and Others $v$ President of Republic of South Africa and Others. ${ }^{11}$ This article examines the extent to which public participation in the legislative process is protected in the Constitution and more specifically, in light of the Merafong case, the justiciability of this right through the courts.

\section{THE CONSTITUTIONAL DUTY TO FACILITATE PUBLIC INVOLVEMENT}

Under previous regimes the majority of South Africans were excluded from public life; ${ }^{12}$ in particular, they were denied the right to vote. In breaking from the old, sections 59(1)(a), 72(1)(a) and 118(1)(a) ${ }^{13}$ introduce a constitutional duty on National Assembly, the National Council of Provinces and provincial legislatures respectively to facilitate public participation when executing their legislative processes.

Even though legislative bodies have discretion in determining what processes and procedures will be utilised to facilitate public involvement, the Constitutional Court set out a test in Doctors for Life International $v$ The Speaker of

6 S 41 (1) (c) provides

All spheres of government and organs of the state within each sphere must provide effective, transparent, accountable and coherent government for the Republic as a whole.

7 One of the values in the founding provisions of the Constitution is stipulated in section 1 (d) as Universal suffrage, a national common voters' roll, regular elections and multi-party system of democratic government, to ensure accountability, responsiveness and openness.

8 S42 (3):

The National Assembly is elected to represent the people and to ensure government by the people under the Constitution. It does this by choosing the President, by providing a national forum for public consideration of issues....

9 S 59(1)(a)The National Assembly must- (a) facilitate public involvement in the legislative and other processes of the Assembly and its committees; ...

S 72(1)(a) The National Council of Provinces must- (a) facilitate public involvement in the legislative and other processes of the Council and its committees; ...

S 118(1)(a) A provincial legislature must- (a) facilitate public involvement in the legislative and other processes of the legislature and its committees; ...

10 S v Makwanyane 1995 (6) BCLR 665 (CC), per O’Regan J, para 329.

11 [2008] ZACC 10

12 Brink $v$ Kitshoff 1996 (6) BCLR 752 (CC) para 40.

13 See fn 9 above 
the National Assembly. ${ }^{14}$ The issues before the Court in the Doctors for Life International case were (i) what the nature of the duty to facilitate public participation is; (ii) whether the legislature had discharged its duty to facilitate public involvement in the legislative process of certain health related legislation; and (iii) what the impact on the validity of such legislation if the facilitation of public involvement was flawed is. The test set is whether the legislature acted reasonably in discharging the duty to facilitate public involvement. The following factors would also be taken into account in determining reasonableness: (i) the nature of the legislation concerned; (ii) the importance of the legislation; (iii) intensity of the impact on the public ${ }^{15}$, and other relevant factors which will depend on the circumstances of each case. Furthermore, at least two elements are encompassed by the duty to facilitate public involvement; first, to provide meaningful opportunities for public participation in the law-making process and secondly, to make sure that people have the ability to take advantage of the opportunities provided. ${ }^{16}$ Sachs J, concurring with the majority judgment, emphasised the "special meaning" ${ }^{17}$ of public participation within our democracy and said the effect of public participation should be that:

"All parties interested in legislation should feel that they have been given a real opportunity to have their say, that they are taken seriously as citizens and that their views matter and will receive due consideration at the moments when they could possibly influence decisions in a meaningful fashion. The objective is both symbolical and practical: the persons concerned must be manifestly shown the respect due to them as concerned citizens, and the legislators must have the benefit of all inputs that will enable them to produce the best possible laws". ${ }^{18}$

This judgment clearly breaks away from the history that saw arbitrary legislative decision and the marginalisation of the majority of South Africans. This also creates an impression that the Constitutional Court is serious about addressing the "injustices of the past" and more importantly that the legislature should be accountable to the people who elected them. Doctors for Life set the standard of the constitutional obligation to facilitate public participation, but a fully fleshed out understanding was to be developed by later jurisprudence. Keeping in mind South African history, one would hope for constitutional protection to be given against arbitrary enactment of legislation.

\section{PUBLIC PARTICIPATION IN CHANGING A PROVINCIAL BOUNDARY}

South Africa has a history of forced removals, issues pertaining to the pass laws and freedom of movement where Bantustan policies were used to entrench ${ }^{19}$, deepen and widen the divide between rich and poor, urban and rural, different races and between classes of citizens. ${ }^{20}$ With the realisation that the administration of cross-boundary municipalities was fraught with

\footnotetext{
142006 (12) BCLR 1399 (CC)

15 Doctors for Life International (fn 14 above) para 128.

16 Doctors for Life International (fn 14 above) para 129.

17 Doctors for Life International (fn 14 above) per Sachs, para 226.

18 Doctors for Life International (fn 14 above) per Sachs, para 235.

19 Ibid.

20 Ibid.
} 
difficulty ${ }^{21}$, government, in abolishing them, had to apply caution as tempers might flare (as the community of Merafong Municipality amply demonstrates) if people perceive that they are not adequately consulted as was done with the legislation such as the Group Areas Act ${ }^{22}$.

In Matatiele Municipality and Others $v$ President of the Republic of South Africa and Others ${ }^{23}$ the constitutional issue was whether the correct procedure was followed when the legislature sought to pass the Twelfth Constitutional Amendment that would in effect alter the provincial boundaries of KwaZuluNatal and the Eastern Cape. The Appellants challenged the constitutionality of the Constitution's Twelfth Amendment Act of 2005 (Twelfth Amendment), as well as of the Cross-boundary Municipalities Laws and Repeal Related Matters Act 23 of 2005 on grounds that the KwaZulu-Natal Provincial Legislature had failed in discharging its duty to facilitate public involvement and therefore Acts were not passed according to the Constitutional provisions. ${ }^{24}$

Section 74(3)(b)(ii) sets out the procedure to be followed in altering a provincial boundary. The provincial legislature(s) province(s) concerned have to approve the Bill or part of the Bill that specifically concerns their province ${ }^{25}$; this affords the province concerned an opportunity to protect its territorial integrity. ${ }^{26}$ As the two provinces affected, the KwaZulu-Natal and the Eastern Cape Provincial Legislature had to comply with section 74(8), however unlike the Eastern Cape; KwaZulu-Natal did not take any steps to involve the public in its decision to support the boundary change. In its decision the Court said:

"[T] he KwaZulu-Natal legislature was required to approve that part of the Twelfth Amendment that transfers the area that previously formed Matatiele Local Municipality from the province of KwaZulu-Natal to the Eastern Cape. The Constitution contemplates that the approval in terms of section 74(8) will be given by a provincial legislature concerned after complying with the provisions of section 118(1)(a)" ${ }^{27}$ (my emphasis)

From the quote above it is evident why the court, in applying the test developed in Doctors for Life International, found the decision by the provincial legislature to be invalid. ${ }^{28}$ What can be learnt from this case is that compliance with provisions that provide for public participation is a neces-

21 Memorandum to the President's Coordinating Council, 1 November 2002: Administration of CrossBoundary Municipalities.

2241 of 1950

23 Matatiele Municipality and Others $v$ President of the Republic of South Africa and Others 2006 ZACC 12, Matatiele 2.

24 S 74(3)(b)(ii).

"(3) Any other provision of the Constitution may be amended by a Bill passed-

(a) by the National Assembly, with a supporting vote of at least two thirds of its members; and

(b) also by the National Council of Provinces, with a supporting vote of at least six provinces, if the amendment-

(ii) alters provincial boundaries, powers, functions or institutions;...

25 S 74(8) of the Constitution

If a Bill referred to in subsection (3) (b), or any part of the Bill, concerns only a specific province or provinces, the National Council of Provinces may not pass the Bill or the relevant part unless it has been approved by the legislature or legislatures of the province.

26 Ex parte Chairperson of the Constitutional Assembly: In re Certification of the Constitution of the Republic of South Africa, 19961996 (4) SA 744 (CC); 1996 (10) BCLR 1253 (CC) para 233.

27 Matatiele 2 (fn 22 above) para 85.

28 Matatiele 2 (fn 21 above) para 89 
sary accompaniment in the legislative process particularly if the legislation has such importance as the alteration of a provincial boundary.

\section{MERAFONG DEMARCATION FORUM AND OTHERS V PRESIDENT OF REPUBLIC OF SOUTH AFRICA AND OTHERS $^{29}$}

In a bid to abolish cross-boundary municipalities two Bills ${ }^{30}$ were passed in the National Assembly and, according to section 74, the legislative process was to be completed in the National Council of Provinces. The following was stated in relation to Merafong Municipality as an example of this concern:

"Merafong City Local Municipality is to be excluded from the municipal area of the West Rand District Municipality and included in the municipal area of the Southern District Municipality. Westonaria is to remain in the West Rand District Municipality". ${ }^{31}$

In compliance with the requirements of the Constitution it was therefore necessary to arrange public participation on the aforementioned legislation under section 118(1)(a). The events played out as follows: the Gauteng Provincial Legislature, through a Portfolio Committee, and the North West Provincial Legislature engaged on the issue with the community of Merafong from which opposition by various community structures were voiced against being incorporated to the North West Province. A negotiating mandate was adopted in favour of what the majority in the community had expressed and in light of "impact assessment and analysis of the public hearing submissions". ${ }^{32}$

Subsequently, the Portfolio Committee met with the Legislature's legal advisors and then the Select Committee on Judicial and Constitutional Matters. As a result of those consultations the Gauteng Provincial Legislature deviated from the negotiating mandate in support of the Amendment Bill that included the Merafong Municipality in the North West Province. In the final mandate the Legislature sighted various reasons for the change. ${ }^{33}$

29 Merafong (fn 10 above).

30 Constitution Twelfth Amendment Bill 2005 and the Cross- Boundary Municipalities Laws and Repeal Related Matters Bill 2005.

31 The municipal area of Merafong described by Map No 5 of Schedule 1 to Notice 1998 of 2005 under the Province of North West.

32 The Portfolio Committee on Local Government -Gauteng "Committee Position at the Negotiation Phase"

33 The Portfolio Committee on Local Government- Gauteng "Committee Position after Consideration of Negotiating Mandates by the NCOP Select Committee" $\cdots$

If the veto of the Gauteng Province applies to the whole Constitution Bill as it relates to crossboundary municipalities, the Cross-Boundary Municipalities Repeal Bill will have to be withdrawn from Parliament, and the local government elections would be conducted within the current municipal configuration, i.e. with cross-boundary municipalities.

If the notion of a narrow interpretation is applied to the provisions of the Constitutional Bill which may be vetoed by a province, the implications are just as extensive as if the whole Constitution Bill is rejected. Let's for argument sake say Gauteng can only veto (reject) the part of the proposed Schedule $1 \mathrm{~A}$ that defines its territory; it will mean that the authorisation to have cross-boundary municipalities is revoked, whilst the current boundary of Gauteng remains the same. The result of this would be that not only West Rand District but also Tshwane, Ekurhuleni and Metsweding would be affected. These municipalities (and their local municipalities where applicable) would have to be disestablished and those areas of the municipalities in question that fall in Gauteng. The crossboundary areas falling in the other provinces would likewise have to be redemarcated into the new municipalities. 
The issues before the court were: (i) was there sufficient public involvement by the provincial legislatures? (ii) was the decision to exclude Merafong Municipality from Gauteng ( the change in the mandate) rational?

\subsection{Reasonableness}

The question of reasonableness surrounds the extent to the public was involved in the decision-making of the Gauteng Provincial Legislature. After receiving legal advice the legislature's modus operandi changed, in that the legislature was informed that it can only vote "aye or nay" as it cannot amend the Bill to incorporate Merafong Municipality into Gauteng. The question arising is whether the legislature was acting reasonably when it did not go back and consult with the public after dramatic change in the circumstances. Van der Westhuizen J, for the majority, found that the previous decisions ${ }^{34}$ on which the applicants relied do not require an ongoing dialogue and that the conduct of the Gauteng Provincial Legislature (not going back to the public) only amounted to "discourteous conduct (which) does not equal unconstitutional conduct which has to result in the invalidity of the legislation" 35 because in this case submissions and public hearings were held which pass the constitutional muster. Therefore the Court found no evidence that the Gauteng Legislature discharged its duty unreasonably.

The Appellants also contended that the legislature was never open to persuasion because the Minister had beforehand stated on a public website that Merafong Municipality would be incorporated into the North West Province ${ }^{36}$ and that decision was made before public participation took place and furthermore, that is was due to political pressure that the Respondents were reluctant to provide reasons for their final mandate. ${ }^{37}$

The Court held that findings are based on the facts and evidence before it; it cannot make a finding on whether there was any political pressure. ${ }^{38}$

\subsection{Rationality}

The reasons given by the Portfolio Committee for the change in the mandate are based on the legal advice received from the state law advisors that a province can only adopt or reject the Constitutional Bill in terms of section 74(8) of the Constitution and that no amendments can be affected in the NCOP. The reasons are the adverse implications of not supporting the Bill which the Committee said included the following: (i) the whole Bill would have to be withdrawn meaning local election would still be held under cross-boundary

The overall complication would be that the current boundaries of Gauteng are still determined with reference to magisterial districts, which are not used or referred to in the Constitution Twelfth Amendment Bill. Consequently, amendments that would be required in the Constitution Bill to address Gauteng's position may be such that it would not be possible to finalise the bill for the Local Government Elections, thus, elections would be conducted within the current municipal configuration."

34 Doctors for Life International (fn 13 above); Matatiele 2 (fn 21 above).

35 Merafong (fn 10 above) para 60.

36 Merafong (fn 10 above) para 47.

37 Ibid.

38 Merafong (fn 10 above) para 48. 
municipalities; (ii) even if the provincial legislature rejects only that part that deals with Gauteng's territory, the effect would be just as extensive as other municipalities would be "disestablished"; and (iii) the Local Government Elections would be affected as Gauteng will still e determined in terms of magisterial districts. The Appellant sought to challenge the rationality of the Gauteng Provincial Legislature on two issues. First, the Gauteng Legislature acted irrational when it abandoned the mandate at the NCOP and voted Merafong into the North West Province. ${ }^{39}$ The Gauteng Provincial Legislature acted irrationally because it failed to provide reasons for abandoning its mandate at the NCOP. ${ }^{40}$ Secondly, the Appellants argued that the decision is factually irrational because the incorporation of Merafong into the North West would adversely affect the lives of the Merafong community. ${ }^{41}$

The test for rationality is whether the exercise of public power is linked to a legitimate governmental purpose. ${ }^{42}$ The Court held, the Gauteng Provincial Legislature's conduct was linked to a legitimate purpose of eliminating cross-boundary municipalities and the creation of viable and economically sustainable municipalities ${ }^{43}$ and therefore rational. The Court also noted that in keeping to separation of powers the judiciary should not substitute with their opinions what they do not agree from the legislature. ${ }^{44}$ According to the majority the obligation to facilitate public involvement does not mean that the public's views will prevail. ${ }^{45}$ The judgement goes further to say that government cannot be expected to be bound by the wishes of the minority and that public participation should supplement elections and majority rule, and "not to conflict with or even overrule or veto them" 46 .

\section{DISCUSSION}

Looking at the reasonable test the factors against which reasonableness is judged are (i)the importance of the legislation to be passed, followed by (ii) the impact the legislation will have on the public, it is difficult to understand why the Court found that is was not necessary for the Legislature to go back to the people of Merafong Municipality once circumstances under which they were consulting changed (by the advice from the legal experts). The impact of re-demarcation has adverse effects on the people's fundamental rights ${ }^{47}$, as discussed by O' Regan J in Matatiele $1^{48}$, if the people directly affected are not meaningfully involved in the legislative process.

The failure to report back to the Merafong community does not according to majority rise to the level of unreasonableness which would result in the

\footnotetext{
39 Merafong (fn 10 above) para 66.

40 Ibid.

41 Ibid.

42 Merafong (fn 10 above) para 63

43 Merafong (fn 10 above) para 96.

44 Merafong (fn 10 above) para 63

45 Merafong (fn 10 above) para 50.

46 Merafong (fn 10 above) para 26

47 S 21(3) of the Constitution. S 10 of the Constitution

48 Matatiele Municipality and Others $v$ President of the Republic of South Africa and Others (1) 2006 (5) BCLR 622 (CC) Matatiele 1
} 
invalidity of the Twelfth Amendment. From the previous decisions ${ }^{49}$ the duty to facilitate public involvement has been described as being central to our constitutional democracy. Sachs J said ${ }^{50}$ "in our country active and ongoing public involvement is a requirement of constitutional government in a legal sense", thus, where the legislature makes a decision, and such decision does not correctly reflect what was deduced during the public participation process, the legitimacy of legislation which flows from such a decision will be tainted. In Doctors for Life the Court also implied that when legislation is passed in a legitimate manner, the general public would be more accepting of such legislation..$^{51}$ In the majority judgment the Court also said:

"Politicians, who are perceived to disrespect their voters or fail to fulfil promises without explanation, should be held accountable. A democratic system provides possibilities for this, one of which is regular elections" ${ }^{\prime 2}$.

The statement above does make sense; however, if public participation becomes an ineffective exercise the only time the public will be able to have a meaningful say in government is once every five years. And that goes against the constitutional principle that our democracy encompasses both representative and participatory democracy ${ }^{53}$.

\section{CONCLUSION}

One of the strengths of the Constitutional Court lies in its ability to safeguard and protect the dignity of minorities and the vulnerable. The fact that the test for reasonableness in the duty to facilitate public involvement has no procedural safeguards ${ }^{54}$ leaves the legislature with ample discretion to meet the just minimums set in both the rationality and the reasonableness tests. The minimalist approach to public participation has created a gap wide enough to let an important piece of legislation which has significant implications on the public to be passed as reasonable. Setting such low standards means that judicial review of the other branches of government is ineffective. This has resulted in what Sachs J once hinted;

"[I]t would be gravely unjust to suggest that the attention the Constitutional Assembly dedicated to promoting public involvement in law-making represented little more than a rhetorical constitutional flourish on its part" ${ }^{\prime 5}$.

The public will, according to the majority, have a meaningful say in the next election $^{56}$.

\footnotetext{
49 Doctors for Life International (fn 13) and Matatiele 2 (fn 21)

50 Doctors for Life International (fn 13) para 231

51 Doctors for Life International (fn 13 above) para 205.

52 Merafong (fn 10 above) para 60

53 S 41(c) of the Constitution

54 Procedure for public involvement was suggested in King and Others $v$ Attorneys Fidelity Fund Board of Control and Another 2006 (4) BCLR 462 (SCA).

55 Doctors for Life International (fn 13 above) para 227

56 Merafong (fn 10 above) para 60.
} 


\section{LAW, DEMOCRACY \& DEVELOPMENT}

\section{BIBLIOGRAPHY}

Buccus, I 'Towards developing a public participation strategy for South Africa's Provincial Legislatures (2006) Special Focus: Centre for Public Participation

Gauteng Department of Development and Local Government Annual Report $2000 / 2001$

Memorandum to the President's Coordinating Council, 1 November 2002: Administration of Cross-Boundary Municipalities

Motala, Z \& Ramaphosa, C 'Constitutional Law: Analysis and cases' Oxford University Press (2002) 9.

Proposals for Boundary Changes- Government Gazette 2818931 October 2005

Sikhakhane, M 'In re: Doctors for Life case and Matatiele case' SAHRC/SAIFAC Seminar on recent Constitutional Court decisions 